\title{
Assessing the State Of Capital Punishment as a Means Of Curbing Violent Crimes In Nigeria
}

\author{
Odulaja Ayorinde Lateef \\ Derpartment Of Sociological Studies Tai Solarin University Of Education, Ijagun, Ijebu Ode, Nigeria
}

\begin{abstract}
The increase in the rate of violent crimesisno longer news in Nigeria, especially the current state of bomb explosion, and robbery and murder. No society exists without some norms and these have translated in many societies as guiding laws which emanated from different socio-cultural experiences. In Nigeria, punishment of such violent crimes as armed robbery and murder by capital punishment or death sentence is still very much in place. This study was intended to appraise the state of capital punishment in Nigeria, looking at its effectiveness in curbing violent crimes. The study used a group of Nigerian youths as a sample, accidentally drawn to appraise the perception of the people on capital punishment, and this study was guided by the abolitionist and retentionist schools whose views and positions were within the tents of retributivism and utilitarianism and control theory respectively. While using simple percentage for data analysis, it was found out that though capital punishment has not produced the expected effect, but was believed to have produced some deterrent value for the offender and the would-be offender. It has therefore been recommended that Nigerian governments at all levels should expedite actions in the area of employment generation and also make policies for community policing and include in the school curriculum security education.
\end{abstract}

Key words: capital punishment, crime, violent crime, utilitarianism, retributivism, control theory.

\section{Introduction}

In every society, there are acts or behaviour regarded as inimical to the sustenance and perpetuation of the entire social structure. These behaviours, being seen as opposed to the norms and values passionately held by the the members of the society do create some kind of disequilibrium and disintegration in the society's integral parts. One of the major ones is crime.

Crime, within this scope of understanding, refers to any act or omission especially of grave nature punishable by law, as forbidden by statute, or injurious to the public welfare(Obioha, 2002) this is an act of violation of societal rules by some members of society, and threatens a desired order. This behaviour targeted at breaking laws, conventions and values of society, is in no way overlooked by the state.

In view of the abysmal effects of criminal behaviour, society through its governments reacts to put crime at bay, hence the emergence of punishment of offenders of societal rules, laws, codes, norms or constitution. These cultural elements of society, when contravened, stand to classify nature of crime and the attendant punishment required for such offences or violations(Obioha, 2002). In other word, punishment of crime serves as a society's desire and equally does serve as a function of crime.

Punishment, as a function of crime, is the infliction of pain or other penalty upon a person or persons for the violation of a social regulations or command. It is also a means by which society tends to curb or obstruct perpetuation of crime. So, punishment may involve loss of money, property, liberty and even in some cases, the loss of live, depending on the kind or form of criminal act committed by the deviant.

One of the four kinds of punishment as categorized by Alli(2001) is capital punishment. Among the four, it is the only one that emphasizes death of an offender. We may believe that its intention is to curb such violent crimes as murder, armed robbery, etc. it is believed within its scope that when applied, then such a deviant act would be abated or less attractive to other members or would-be-offenders in society.

In Nigeria today, the law that stipulates capital punishment(death penalty) for violent crime offenders is still in place. just like the criticism against and appeal to the Gambian President when he decided to and began to carry out death penalty of the convicts on death row in September this year,, Adams Oshiomole, the governor of Edo State, Nigeria, was criticized and pressured when he decided to direct the killing of the inmates sentenced to death by the court of law in the state.

In Nigeria, like many other countries,capital punishment is facing an increasing call for eradication, especially by the human rights groups and religion-based non-governmentalorganisations. Some of them have premised their argument on ineffectiveness and social dysfunction of the punishment while others have always premised theirs on respect for the dignity of human life, considering the fact that after all, it is the negative prevailing social conditions that prompted the offenders into committing such a crime. Other abolitionists have 
argued the fact of fallibility of the judicial process which makes an innocent person suffers what he/she is never involved in.

But then, sociologically capital punishment as a way of curbing violent crime is a product of social thought; surprisingly with its discrimination and frantic call for the abolition, then one can rightly say that there is a change in human social thought from brutality to human nature. Looking at it further, sociologically, the change iss an influence of adjustment in our social structure and the thought pattern of members of society (Obioha,2002). This change calls for assessment of the punishment, which borders on its functions, idealism, reality and people's perception.

\section{Statement Of Problem}

Nigeria ranked the fifth among the six countries of the world in which largest overall number of executions took place between 1994 and 1999 and the first in Africa. In spite of this, capital offences are still making waves, thereby denying the punishment the expected deterring effect. According to Okunola (2002), armed robbery rose from 7.1 per cent in 1986 to 13.2 per cent in 1996. From the foregoing, capital punishment has not been able to deter people from engaging in violent crimes. So, the only person deterred is the offender and not the potential ones. This was also backed by the UN in 1998 as reported by Ilechukwu that 'this research has failed to provide scientific proof that executions have a greater deterrent effect than life imprisonment,

Also, Amnesty International in 2004 reported that 'scientific studies have consistentlyfailed to find convincing evidence that the death penalty deters crime more effectively than other punishment. As reported by Amnesty International, the British executioner, Albert Pierre asserted that 'I do not now believe that any one of the hundreds of executions I carried out has in any way acted as a deterrent against future murderer. Capital punishment in my view, achieved nothing except revenge'. Then the question asks: does revenge bring about solution or aggravation to crime?

Another problem associated with death penalty is the fallibility of judicial process. Ilechukwu (2004) emphasized the discoveries from study that no justice system in the world can be free from error in imposing the death penalty. If such an error has ever occurred, then justice is questionable and a social evil would have been unjustifiably meted out to an individual and his family, and this is capable of creating other social problems.

\section{Objectives Of The Study}

The objectives of this study include:

a. To know whether or not Nigerians would want capital punishment abolished

b. To know what Nigerians want the punishment to achieve

c. To know whether or not the law of death penalty affects the rate of violent crimes in Nigeria.

\section{CRIME AND PUNISHMENT}

\section{Literature Review}

Punishment, is a word coined from the Latin word 'punire' which implies the infliction of pain or other penalty upon a person for the violation of regulation or command(Achilike, 1999). In other word, a person deserves some infliction of pain or other penalty for behaving in a way that violates the socially approved rules, codes or laws. One would have a wider view of punishment when considering the concept of crime as defined by Onoge(1993) as an act or omission which renders the person doing the act or making the omission liable to punishment under any order in council, ordinance, or law or statute.

Eitzen(1980) was of the view that crime would keep destroying the stability relevant for the maintenance and sustenance of an orderly society if left unchecked and renders every member of the society a potential victim of life discomfort and insecurity. From the foregoing, it is clear that society is not willing toaccommodate any form of violation of consciously designed rules or law, having considered that such a violation threatens its perpetuation and order. Against this background, punishment is being is being set out to curb crime rate. Of course, the nature of crime determines the attendant punishment required, and this varies from one society to another.

Flew Anthony highlighted four criteria for the use of punishment in its primary sense:

a. Punishment must involve an evil, unpleasantness to the victim or offender;

b. Punishment must be related to the offence, actual or supposed, that is, it must inflicted as a response to an offence and this presupposes that an innocent person must not be punished; if otherwise, it is immoral and unjust;

c. Punishment must be applied to an offender, actual or supposed. This is to say that there must be a logical connection between the evildone, the offence committed and the sufferer-meaning that a person becomes liable to punishment only when he has committed an offence.

d. Punishment must be imposed by authority conferred through institution against the rules of which the offence has been committed, that is, it must be inflicted by a legally recognized authority. 


\section{CAPITAL PUNISHMENT}

One of the major violent crimes in Nigeria- murder is what is against the provision of fundamental human rights to life as provided for in Chapter iv, section 33 of the constitution of the Federal Republic of Nigeria, 1999. Therefore, the violation of these rights and others which involves the robbery with arms attract capital punishment/death penalty in Nigeria.

Death penalty involves legally imposed sentence of death penalty on an offender for committing a particular offence or crime termed 'capital' by the state. This is one reason Longman Dictionary of Contemporary English defines it as 'punishment by legal killing'. However, what is regarded as capital offence and what forms capital punishment varies from one country to another. For instance, in Singapore, capital offences or violent crimes include drug trafficking, fire arms, offence against the president's person, murder, robbery, kidnapping, to mention but few.(all of these attract mandatory death penalty). In Nigeria, murder, armed robbery and treasonable felony(especially by coup de'tat) attract death penalty.

Giddens(2001) describes capital punishment as 'the state-sanctioned execution of a person who has been convicted of a crime that is punishable by death'. It is a death penalty executed after a process of law carried out by a society's duly constituted apparatus or apparatuses. It is a legal infliction or imposition of death as a penalty on an offender for violating criminal laws made by the state. Therefore, it is the responsibility of the criminal justice system as the apparatus of the state to carry out the processes

It is however worthy of note to briefly make mention of two schools of thought on capital punishment. The first clamours for its abolition while the other retention. Some of the abolitionists include Correta King, the widow of the murdered civil right crusader, Martin Luther King Jnr., Catholic Pope, Amnesty International, etc. their argument is summarized in the following highlights:

a. Evil deed not redeemed by evil deed of retaliation

b. Justice is never advanced in taking of human life

c. Morality is never legalized by murder

d. The death penalty is a communal celebration of sadism, vengeance and vendetta

e. It does not rehabilitate or reform as the punishment is ultimate

f. The life of each person remains sacred and inviolable, even when the individual chooses to be deviant, a murderer or an assassin

g. The death penalty is not morally acceptable because it makes correction impossible and the incorrigible will not take correction

h. It is an act of revenge by the state, not to correct or prevent further crimes

i. The fallibility of the criminal justice system

The retentionist school has the likes of Lloyd George, Hugo Adam Bedau, John Locke, BadamosiBabangida, YahyaJammeh, Adams Oshiomole, and a host of others. Some of their arguments are as follows:

a. No one can vouch for the incarcerated or released murderer that he will not kill again, therefore the only way to guarantee that no convicted murderer ever commits another murder is to kill them all.

b. A person forfeits his or her right to live when found guilty of taking another man's life, because he has abused or violated the right to life of his victim

c. Why would right to life or dignity of life be claimed for an offender who took other person's life?

\section{METHODS OF CAPITAL PUNISHMENT}

The methods vary from one country to another. They include:

a. Hanging: in which death is imposed by damaging the spinal cord or by asphyxiation. This is mostly used in Nigeria, and usually takes place in the prison's apartment called gallows.

b. Shooting: in which the convict is killedby one or combination of gun shooting. This practice was last practiced in Nigeria during the military rule.

c. Electrocution: in which death is brought upon the convict by cardiac arrest and respiratory paralysis; electric current is passed into the convict's body until he gives up the ghost. This method has been reported to be to be used in the US.

d. Lethal Injection: this is a continuous intravenous injection of lethal quantity of short acting barbiturate in combination with some quantity of chemical paralytic agent into the body of the convict. This has also been found to be common in the US. Oklahoma was the first state in the United States to authorize lethal injection to kill convicts in 1977. A total of 36 states have been reported to have authorized this method. The total number of convicts killed with this method in the US, as recorded in the US department of justice, between 1977 and 2009 is put at 1,016 representing 85.5 per cent of the total 1,188 convicts killed.

e. Gassing: in which the convict is made to inhale some poisonous gas, such as cyanide gas. The gaseous process of killing condemned inmates takes place in a gas chamber. 
f. Beheading: in which the inmate's head is cut off the body by means of a sharp blade such as guillotine or sword. This method is also referred to as decapitation. It is mostly used in Saudi Arabia and other Islamic countries.

g. Stoning: the convict is killed by being pelted with a large quantity of stones. This method is in force in Islamic countries operating sharia law. In Bauchi State, Northern Nigeria, a sharia court pronounced death penalty on a female, Hajara Ibrahim by stoning for committing adultery.

\section{UTILITARIANISM}

\section{Theoretical Framework}

The position of the philosophical theory is better exemplified by the ancient Greek Philosopher, Plato. Plato, in his dialogue with Socrates, asserted that punishment is not inflicted by a rational man for the sake of the present (the crime that has been committed), but for the future; to prevent either the same man or by the spectacle of his punishment someone else, from doing wrong again. He had earlier conversed that people would not consider the wrong the man had done, but would rather concentrate on the punishment being meted out to him as unnecessary.

So, from Plato's submission, punishment is to prevent great evil and promote or increase happiness. The first evil punishment prevents is future offence and secondly the offender, in that he will refrain from engaging in the act again, and this in a way take away people's unhappiness and increase happiness.

John Locke, a foremost retentionist, has argued that capital punishment is needed to protect our society by deterring crime through example. In other words, a murder-offender should be killed so that he will not live to commit the crime again; and secondly deters potential offenders from going in the similar direction. This, the utilitarians believe, contributes to a greater balance of happiness in society. However, in swift reaction, the abolitionists have argued that death penalty does not deter future offenders.

The second philosophical perspective is retributivism whose position findsexpression in the Bible words: 'eye for eye, tooth for tooth, hand for hand, foot for foot, life for life' (Exodus 21:23-24). Punishment is justified because it is what the offender deserves; lawbreakers must repay the damage he or she has caused. The retributivists argue that criminals deserve punishment simply because of the crime they have committed. They believe that the murderer should be killed because he has killed someone else. The argument is that punishment should be commensurate to the crime committed; that is it should be to the harm done the victim.

The retributivists have further distinguished between two types of retributivist punishment. First, lextalionis, which involves punishment in kindi.eeye for eye, wound for wound and life for life. Second, lexsalica retribution involves punishment through compensation, and the harm inflicted or done can be repaired by payment or atonement. From the foregoing, it is clear that capital punishment is most often associated with lextalionis retribution.

In relating these two theories to Nigerian society, the government may have decided to retain $\mathrm{d}$ punishment so as to de3ter would be offenders and also prevent the offenders from further engaging in the crime. The government might have also decided to pitch tent with the retributivists for the contravention of the laws. This brings to mind the death penalty on the coup plotters which is on the side of retribution based on vengeance against the offender, and not to deter them. However it could be deduced that the motive behind reintroduction of death penalty by decree 47 of 1970 for robbery and fire arms by the then head of state, General Yakubu Gowon was to deter potential offenders who were mostly thought to be among the discharged and demobilized soldiers of the Nigerian army after the civil war.

\section{CONTROL THEORY}

Control theory sees crime as the outcome of imbalance between impulses towards criminal activity and controls which deter it(Giddens,2001:685). They further agree that offenders are rational beings who will act to maximize their own reward unless they are immobilized to do so through either social or physical controls. The central idea of this theory is that humans seek a maximum of pleasure to avoid pain from crime.

This sociological approach suggests that punishment or fear of punishment will deter people from committing crime. The interest of the theorists basically lies in the question of why people do or do not engage in crime. Interestingly, one key assumption of this theory is that if the perceived costs of crime outweigh the perceived benefits of crime, rational people will choose to steer clear of such deviant acts as murder, armed robbery, etc.

The argument above could be found to have explained one reason capital punishment is considered as a worthwhile cost in some societies(including Nigeria), in that it outweighs the benefit of the crime(what profit does a man have to commit the crime and not live to enjoy the benefit accruable?).

On this basis, it could be argued that if punishment(in the case of death penalty) is severe and swift, the rate of crime or other deviant acts would be minimized/reduced in two ways. First, the offender is being deterred and refrained from exhibiting the same behaviour in the future. Second, other potential offenders, having seen 
the consequences of the crime, will become more reluctant to commit it, for they would not want to experience the attendant 'evil'- the death penalty(Denisoff et al, 1979:394).

In conclusion, the overall argument of explaining the essence of death penalty in relation to violent crimes from the control theory propositions is that death penalty deters or prevents the offender from repeating the act and would be offenders from engaging in the act.

\section{Methodology}

Descriptive survey method was used for this study. Its population constituted youths among Nigerian students of OlabisiOnabanjo University, Ago Iwoye and convicts on death row in Nigerian Prison, Abeokuta. Accidental sampling technique was used to select 100 respondents among the first study population while all the 30 inmates on death row were selected.

Questionnaire was used to gather the primary data while the secondary data were gathered from the records department of the Nigeria Police, Ogun State command, Eleweeran, Abeokuta, and the High Court of Justice, Abeokuta, Ogun State. The primary and secondary data were analyzed, using simple percentage method.

\section{Findings And Discussion}

The demographic data of the first sample(100) showed that the study was not gender biased as the male respondents were 53 , constituting 53 per cent while the female were 43,43 per cent. But there was a sharp difference in the second sample; while the males were 29(97 per cent) there was only one female( 3 per cent). This is instructive to say that more male engage in violent crimes than female folk.

TABLE 1 EFFECT OF CAPITAL PUNISHMENT ON VIOLENT CRIME REDUCTION

\begin{tabular}{|l|l|l|}
\hline RESPONSE & RESPONDENTS & $\%$ \\
\hline NO & 71 & 71 \\
\hline YES & 29 & 29 \\
\hline TOTAL & 100 & 100 \\
\hline
\end{tabular}

The table 1 above shows the view of the 71 per cent respondents that capital punishment does not have effect on violent crime; 29 per cent believed it has effect on the crimes. The reason for this first view through the open ended questions revealed that poor economic condition would always provoke individuals to engage in armed robbery so as to survive the unpleasant hardship. The major reasons behind the 29 per cent include: reduction in the number of the criminals (by their demise); fear of death(cost of the crime) has been restraining some potential offender. One person that would also argue in line with the 29 per cent is Adams Oshiomole, Governor of Edo State, SouthSouth Nigeria. He was reported by the Monday, $5^{\text {th }}$ November, 2012 Vanguard Newspaper to have hinged his decision to sign the death warrant of the two death convicts on the need to deter or refrain the would be offenders, condemning the barbaric act of the two convicts found guilty by the supreme court of Nigeria.

TABLE 2 ABOLITION OR RETENTION OF CAPITAL PUNISHMENT

\begin{tabular}{|l|l|l|}
\hline Response & No of respondent & $\%$ \\
\hline Should be abolished & 39 & 39 \\
\hline Should be retained & 61 & 61 \\
\hline Total & 100 & 100 \\
\hline
\end{tabular}

From the table above, 61 per cent of the respondents wanted the punishment retained while 39 per cent wanted it abolished. Here the retributivist position is well accentuated. In spite of the high percentage view of non-effect of the punishment, more than 60 per cent still wanted it retained. The argument posed by the 29 per cent respondents could make a good sense here. It is also instructive to state that Nigerian youths want the punishment to create fear as a form of deterrence and also as revenge. In Nigerian society, youths are so violent to the extent that they harbor an act of violent crime. For this reason, recently, as reported by the Nigerian Tribune Newspaper a mob killed suspected robbers in Mushin, Lagos and on Tuesday, $13^{\text {th }}$ November, 2012 The Punch Newspaper reported a mob killing robber suspect in delta state. This is barbaric though, it shows that the people desire that such a condemned person should be made to face death penalty.

\section{THE PRISON FINDINGS}

The distribution of the prison respondents according to the violent crime committed reveals that there were more inmates of armed robbery crime than murder as the former inmates represented 80 per cent and the latter, representing 20 per cent respectively. This may have revealed the state of poor economy of the nation which has compelled young people to engage in such crimes. 
It was revealed during interaction session with the inmates that they wished they never committed the offence. Many of them showed deep remorse for their offences, and some proved to have become children of God through Christian faith in the Lord Jesus Christ. Among them was a man who was regarded as pastor, because of the renewal of his mind and repentance, and he was the one in charge of Christian fellowship for the inmates. Notwithstanding the foregoing, the abolitionists' claim and hatred for such crimes would make Nigerians to call for the execution of the offenders.

THE NIGERIA POLICE FINDINGS

TABLE 3: NUMBER OF PERSONS INVOLVED IN AND ARRESTED FOR ARMED ROBBERY AND MURDER IN OGUN, NIGERIA STATE BETWEEN 1999 AND 2003

\begin{tabular}{|c|c|c|c|c|c|c|c|c|c|}
\hline \multicolumn{5}{|c|}{ ARMED ROBBERY } & \multicolumn{4}{|c|}{ MURDER } & \multirow{2}{*}{$\begin{array}{l}\text { OVERAL } \\
\text { L TOTAL } \\
\\
\text { OVERAL } \\
\text { L } \\
\text { TOTAL }\end{array}$} \\
\hline $\begin{array}{l}\text { YEAR } \\
\end{array}$ & MALE & FEMALE & TOTAL & $\%$ & MALE & FEMALE & TOTAL & $\%$ & \\
\hline 1999 & 100 & 30 & 130 & 17 & 40 & 10 & 50 & 13.3 & 180 \\
\hline 2000 & 100 & 20 & 120 & 16 & 30 & 5 & 35 & 9.3 & 155 \\
\hline 2001 & 142 & 6 & 148 & 19 & 68 & 9 & 77 & 20.4 & 255 \\
\hline 2002 & 170 & 3 & 173 & 23 & 87 & 11 & 98 & 26 & 271 \\
\hline 2003 & 189 & 1 & 190 & 25 & 110 & 7 & 117 & 31 & 307 \\
\hline TOTAL & 701 & 60 & 761 & 100 & 335 & 42 & 377 & 100 & 1,138 \\
\hline
\end{tabular}

Source: The Nigeria Police Force, Ogun State Command, Abeokuta, Nigeria

From the table above, the number of people involved and arrested for robbery between 1999 and 2003 was 761(67 per cent) which is higher than number of murder put at 377(33 per cent). We can also see that more males were involved in violent crimes than females. We can also see a general decline in both crimes in the year 2000 while they were on consistent increase from 2001 to 2003. All these occurred despite the existence of capital punishment.

\section{FINDINGS FROM THE COURT}

The highlight of data gathered from court 9 of Ogun State Court of Justicein Abeokuta:

1. RFT/12/98: Attorney General vs S.B: SB was convicted on $14^{\text {th }}$ January, 2000 of armed robbery.

2. RFT/34/97: Attorney General vs MN: MN was sentenced to death for robbery on $25^{\text {th }}$ January, 2000.

3. RFT/43/97: Attorney General vs SA; SA was also sentenced to death for robbery on 11 February, 2000.

4. $\mathrm{AB} / 23 \mathrm{R} / 2000$ : The State vs L.S. and 2 others; they were convicted on $1{ }^{\text {st }}$ August, 2003 for armed robbery.

5. RFT/3/98: Attorney General vs L. O. and 2 others; they were convicted of armed robbery on 21 May, 2004.

Note: For the sake of confidentiality, alphabets were used to represent the convicts.

Surprisingly, notwithstanding the punishment, the rates of violent crimes and the people involved are on the increase, as we can see in table3.

\section{Conclusion}

From the study, therefore the following conclusions are made:

1. Nigerian youths do not want capital punishment abolished; even though it is believed in violent crimes have not been really curbed by the punishment.

2. What Nigerians may want capital punishment to achieve is primarily revenge and fear that will prevent potential offenders.

3. This is further concluded that Nigerian youths havefavouredutilitarianand retributivist position as well as control theory on capital punishment.

4. Males are more involved in violent crimes than females.

5. Law of death penalty has not really affected the rate of violent crimes in Nigeria. This can beattributed to poor economic conditions and since the offenders felt they must survive, hence the urge to get involved in robbery. 


\section{Recommendation}

Based on the findings, we can recommend that capital punishment should be retained to check the violent behaviours of the non-conformist in our society. Abolition of the law might lead to unprecedently geometric increase in violent crimes in Nigeriansociety. As the utilitarian and control theorists have argued the deterrent force of the punishment, we believe capital punishment serves as a force which creates fear in some potential/would-beoffenders, therefore refraining from such acts of evil.

Introduction of crime and security education should be included in the school curriculum from primary to tertiary institutions of education. There should also be improvement in the economy that would create job opportunities for the youths and other unemployed people. This is because most people who engaged in robbery had attributed their actions to unemployment.

The government at all levels should also be procreative by establishing or encouraging community policing as a method of preventing violent crime, especially robbery.

Also, proper and painstaking trial of the accused personsof violent crimes should be certain and ensured, especially for those who were not caught right in the act, so as to rule out fallibility of the criminal justice system.

\section{References}

[1]. Achilike, J.C.(1999)Two theories of punishment: A reconciliation in Balogun .O.et al Philosophy of law, Ibadan: Bennel Books.

[2]. Alli,A.S.(2001) Philosophical problems of punishment in OduwoleE. et al fundamentaltheories and issues in ethics, Ibadan Bennel Books.

[3]. Denisoff R.S et al (1975) An introduction to sociology, New York, Macmillian publishing Co Inc.

[4]. Egbara, G. sharia: another woman faces death by stoning in Bauchi, Daily Independent Wednesday, October 13,2004 pg1.

[5]. Ehusani, G. Revisiting the death penalty The justice vanguard, June7,2004,pg12.

[6]. Flew, A. (no date) The justification of punishment inactionAB(ed).The philosophy of punishment. New York.

[7]. Giddens, A.(2001)Sociology $4^{\text {th }}$ ed UK, blackwell publishers.

[8]. Ilechukwu,L. C.(no date)Capital punishment and the rest of us, Justice vanguard, Monday July 26, 2004pg 13-14

[9]. Longman dictionary of contemporary English, $3^{\text {rd }}$ edition, English research education Ltd.

[10]. Obioha,E.N. (2002) Punishment in society in Isiugo- AbanihereU.C. et al currents and perspectives in sociology, Lagos, Malthouse Ltd.

[11]. Obiora, I.The death penalty debate justice, Vanguard Monday July 26, 2004.

[12]. Okunola,R.A (2002) Crime in societyin IsiugoAbanihere U.Cet alcurrents and perspectives in sociology. LagosmalthouseLtd. 